Société d'histoire de la révolution de 1848 et des

révolutions du XIXe siècle

16 | 1998

1848. Un modèle politique à l'épreuve

\title{
Le phénomène électoral dans le sud de l'île-de- France sous la Seconde République
}

\section{Serge Bianchi}

\section{OpenEdition \\ Journals}

Electronic version

URL: http://journals.openedition.org/rh19/125

DOI: $10.4000 /$ rh 19.125

ISSN: $1777-5329$

\section{Publisher}

La Société de 1848

\section{Printed version}

Date of publication: 1 June 1998

ISSN: 1265-1354

Electronic reference

Serge Bianchi, "Le phénomène électoral dans le sud de l'île-de-France sous la Seconde République », Revue d'histoire du XIXe siècle [Online], 16 | 1998, Online since 04 September 2008, connection on 01 May 2019. URL : http://journals.openedition.org/rh19/125; DOI : 10.4000/rh19.125

This text was automatically generated on 1 May 2019.

Tous droits réservés 


\title{
Le phénomène électoral dans le sud de l'île-de-France sous la Seconde République
}

\author{
Serge Bianchi
}

\section{ABSTRACTS}

Based on archives whose exploitation was made easier by the recent publication of a research guide dedicated to the history of Essonne in the middle of the XIXth century, the articles analyses the way presidential and legislative and cantonal and local elections between 1848 and 1852. It explains both the high turnout at the polls, compared with what it was during the revolutionary period, and the high activity engaged during the election campaigns by the notables who were already there under the previous regime. The article then shows the emergence of a new election behaviour which, after a good deal of experimentation, became that of a rural milieu which massively rallied the party of order and Bonapartism despite the existence of a hard core of Republican or Socialist opponents.

À partir d'un ensemble d'archives dont l'exploitation a été facilitée par la parution récente d'un guide de recherches consacré à l'histoire de l'Essonne au milieu du XIXe siècle, l'article analyse en détail le déroulement et le résultat des élections présidentielles, législatives, cantonales et locales entre 1848 et 1852 . Il rend compte à la fois de la participation importante du corps électoral, comparée à ce qu'elle fut dans la période révolutionnaire, et de l'activité déployée pendant les campagnes électorales, menées dans une grande continuité par les notables déjà en place sous le régime précédent. Il montre ensuite l'émergence d'un comportement électoral qui, 
après quelques tâtonnements, sera celui d'un milieu rural rallié massivement au parti de l'ordre et au bonapartisme malgré l'existence de noyaux d'opposition républicains ou socialistes.

INDEX

Mots-clés: Elections, Seconde République 